Barbara Maria Sageidet is post-doctoral research fellow at the Department of Early Childhood Education, University of Stavanger, Norway. She has a background in botany, ecology, paleoecology and soil sciences, with a PhD related to soil micromorphology. Since 2007 she has worked in the field of early childhood education with a research focus on science education, sustainability and inquiry learning in the kindergarten.

\title{
Norwegian early childhood teachers' stated use of subject- related activities with children, and their focus on science, technology, environmental issues and sustainability
}

\begin{abstract}
This paper presents Norwegian early childhood teachers' own evaluations of their practices and interests, and of their kindergarten's focus, related to daily activities with children. The purpose of this study was to examine the focus and priority given to activities related to science, technology, environmental issues and sustainability, in comparison to other subjects. Ninety-three randomly selected early childhood teachers completed semi-structured questionnaires. The results show that most of them are personally interested in science-related subjects. They state that their activities with the children mainly consist of nature- and outdoor-related subjects, followed by social competences, language stimulation and physical education. Activities related to chemistry, geology, physics, technology, gardening and sustainability are infrequent.
\end{abstract}

Science-related activities are a natural part of many interdisciplinary themes. Appropriate science competence among early childhood teachers is necessary to increase children's opportunities to gain specific science-related experiences.

\section{INTRODUCTION}

While science was hardly mentioned in the Norwegian government's white paper for an early start to a lifelong learning process in 2006 (Ministry of Education and Research, 2006), the Norwegian government's new strategy for the promotion of science and mathematics education ('Realfagssatsingen') 2015-19 (Ministry of Education and Research, 2014, 2015, cf. 2010; Rambøll, 2015) do include the kindergarten.

The recruitment to science-related courses is an international challenge (Bowman, 1999; European Commission, 2004; Ministry of Education and Research, 2010, 2013). Even though an improvement is visible, the pupils' still relatively weak achievements in science subjects underline the need to reflect further on early science education in Norway (Grønmo, Onstad, Nilsen, Hole, Aslaksen \& Borge, 2012; Kjærnsli \& Olsen, 2013). 
Engaging young children through stimulating and cognitively facilitating activities will enhance their development. Multiple research studies have shown a connection between early explorations and experiences with science and nature, and the development of interest, motivation, and skills in science, literacy and numeracy, later in school and in adult life (French, 2004; Hope, Schachter \& Wasik, 2013; Johnston, 2005; Sylva et al., 2007). They underline sociocultural learning theories, describing children's learning through activities, experiences and situations, and through interaction with their physical environment (Lave \& Wenger, 1991; Rogoff, 2003; Säljö, 2001; Vejleskov, 1999; Vygotsky, 1986).

So far, we have no overview of the science-related practices and competences of early childhood teachers in Norway (Ministry of Education and Research, 2013, 2014). This study will help to create such an overview, and contribute to the relatively few studies on the reflections of kindergarten staff on their own theory and practice (Alvestad \& Løvberg, 2005; Fayez, Sabah \& Oliemat, 2011; ÄrlemalmHagsér \& Sandberg, 2011).

The aim of this study was to survey the practices in the everyday life of Norwegian kindergartens, related to activities with children and their subject-related focuses. For this purpose, 93 randomly selected early childhood teachers were asked to answer a semi-structured questionnaire. The answers they gave to both open and closed questions, provided comprehensive data material with a potential for analysis from various perspectives. This paper presents only those questions and results that concern the early childhood teachers' own interests, and the focus and priority given to activities related to science, technology, environmental issues and sustainability, as realized by the early childhood teachers themselves.

\section{THEORETICAL AND CONTEXTUAL FRAMEWORK}

Learning in kindergartens is associated with groups of many children and few adults involved in everyday and subject-related activities. The learning processes in such communities are conceptualized in sociocultural learning theories (Lave \& Wenger, 1991; Rogoff, 2003; Vygotsky, 1986). These theories explain that practical activities and social contexts are essential to promote learning processes in young children.

Although controversy surrounds the way learning should be supported in kindergartens (Berge, 2012; Eshach \& Fried, 2005; Johansson \& Samuelssen, 2009; Thoresen, 2009), the kindergarten's role as an area for lifelong learning is increasingly being emphasized (French, 2004; Ministry of Education and Research, 2009, 2011; Rogoff, 2003; Østrem, 2007).

The Norwegian Framework Plan for the content and tasks of a kindergarten (Ministry of Education and Research, 2011) describes various subject areas. The subject area "nature, environment and technology" is in focus of this study. It includes the science, technology, environmental issues and sustainability. The Framework Plan requires early childhood teachers to provide favourable conditions for the growth of children's interest in these subjects. The new government's strategy for science education 2015-19 (Ministry of Education and Research, 2015, cf. 2013) highlights the importance of competences and further work on this subject area in the kindergarten (cf. Rambøll, 2015). The Framework Plan is just a starting point for local planning and implementation, and allow for individual interpretations by the staff in the various kindergartens (cf. Alvestad, 2004). Individual early childhood teachers have a key role in defining the object of learning and choosing how to work on it with the children (Alvestad \& Løvberg, 2005; Lerkkanen et al. 2012; Thulin, 2006). Their choices and priorities determine the activities actually performed with the children, the quality of such activities and the quality of science education in the kindergartens. 
Two main criteria are useful to investigate how far kindergartens provide young children with opportunities for exploration in the science, technology, environmental issues and sustainability: the quality, and the quantity (amount or frequency) of exposure to new knowledge (Kilgore \& Pendleton, 1993). Science-related activities in kindergartens, have seldom been evaluated in terms of their frequencies, but have mostly been investigated in terms of their quality (Hammer \& Min He, 2014; Kallery, 2004; Rambøll, 2015; Sträng \& Åberg-Bengtsson, 2009; Sylva et al., 2006; Thulin, 2006; Zetterqvist \& Kärrqvist, 2007). Fayez et al. (2011) examined Jordanian early childhood teachers' perspectives on science teaching and learning by the use of a mixed method approach including a questionnaire. The quantitative part of their study showed that Jordanian early childhood teachers generally had positive attitudes towards science independent of their education or experience. Nevertheless, they spent less than 30 minutes per week on science teaching with the children. Kallery and Psillos (2001) examined kindergarten teachers' knowledge and understanding of science and investigated how these teachers used this knowledge in practice. In a semi-structured questionnaire, the teachers were asked to explain natural concepts and phenomena chosen from the curriculum and from children's questions. The findings of this study show that teachers' content knowledge in science and their understanding of the concepts and phenomena they introduce to young children was rather limited. Tu (2006) mapped the availability of science materials and equipment, and their actual use by 20 early childhood teachers during activities with the children. He found only $4.5 \%$ of the observed time of teacher-led activities as directly related to science learning. Hope et al. (2013) explain the use of scientific methodology together with children, and its support to children's language, literacy, numeracy and science development. Between 2008 and 2012, Sundberg and Ottander (2014) followed 65 students enrolled in early childhood teacher education in Sweden, and asked them to describe their competence in and attitudes towards science and science teaching, at five subsequent stages of their study program. Among the answers to semi-structured questionnaires, Sundberg and Ottander (2014) could not find any plans for purposefully designed activities with children that would focus on learning about nature or developing scientific skills.

\section{METHODOLOGY}

\section{Research questions and definitions}

This is a quantitative study, a small survey, related on subjective evaluations of early childhood teachers in a questionnaire. Even if case studies or observations may give more detailed and better comparable results (Lerkkanen et al. 2012), self-evaluations were used in this study to achieve an overview based on a considerable number of Norwegian early childhood teachers, about the most frequently used subject areas for everyday activities with children.

The early childhood teachers were asked about the subject-relations of their own daily activities with the children, of their kindergarten's focuses, and of their own interests related to science, technology, environmental issues and sustainability. This study will try to answer the following research questions:

What are the most frequently used subject areas for activities with children in the everyday life of some Norwegian kindergartens, with a special regard on science, technology, environmental issues and sustainability? Can we see any relations between these priorities and the early childhood teacher's interests related to science? What can we learn from the study to strengthen the role of science, technology, environmental issues and sustainability?

Jonassen \& Rohrer-Murphy (1999, p. 64) define activities as "the human interactions with the objective world and the conscious activities that are a part of those interactions". The present study is concerned with an activity's focus, as the focus or object is what differentiates one activity from another, and what determines the activity's orientation and what constitutes the real motive for its 
realization (Thulin, 2006; Zacharos, Antonopoulos \& Ravanis, 2013). The present study does not differentiate between formal and informal learning activities or situations (cf. Berge, 2012), but is based on the early childhood teacher's subjective conception of her or his own activities with the children.

The early childhood teachers' activities as referred to in this study, represent exposures to learning opportunities for children in the kindergartens, and this study examines the usual everyday quantity of them. The data of this study will hardly be suitable to evaluate aspects of the quality of the activities with the children, apart from the recognition that quantity is also a criterion for quality (cf. Jonassen \& Rohrer-Murphy (1999, p. 69). In this way, the answers to the questionnaire are presumed to give an estimation of the obtainability and frequency of such learning opportunities, based on the subjective evaluations by the early childhood teachers.

There were no preset definitions of the terms activity, interest (n.d. 2011), or of the various subjects in the questionnaire. According to Sjøberg (2009), there should not be a difference between the researcher's definition of a term and the definition for the same term among normal people, because only then practice related communication is possible, including any challenges concerning differences in understanding. Terms like 'physics', 'chemistry', 'geology', and 'sustainability' appear without definitions in many documents, relevant for early childhood teachers, for example Rambøll (2015), and Ministry of Education and Research (2015). Misunderstandings and misinterpretations of such terms may appear, and this may also have been a challenge for the informants of this study.

\section{Method, data collection and process}

The data were collected by the use of a semi-structured questionnaire with open and closed questions, and presented by use of SPSS (Johannessen, 2009). A questionnaire is a common tool to investigate obtainability and frequency, and it is suitable to investigate interests (Van Peer, Hakemulder \& Zyngier, 2012). The questionnaire was send by e-mail to 142 randomly selected kindergartens in Norway - both regular kindergartens and nature kindergartens - after a personal request by telephone. The addressees are members of the kindergarten stuff whose role is that of a pedagogical educator for groups of children, called early childhood teachers in this study.

\section{The questions}

Initially, the early childhood teachers were asked for their gender, age and education. The questionnaire covers about 20 questions, but only eight of them were selected for this study. Question 1 was: "What is the superior focus area of your kindergarten?" The answers to this open question were categorized,and presented in Figure 1. Questions 2 was: "What do your kindergarten focus on, on an average day?" The informants could choose among 13 alternatives for answering to this closed-ended question (see Figure 2). These alternatives include all subject areas of the Framework Plan, but are more detailed for the subject area 'nature, environment and the technology' (Ministry of Education and Research, 2011). Question 3 and 4 asked for the subject-relation of daily activities and their frequency, both indoors and outdoors (Figures 3 and 4). The alternatives for questions 3 and 4 concern some of the themes stated in the Framework Plan under the subject area 'nature, environment and technology' (animals, bird species, plant species, climate, sustainability, environment, biodiversity, experiments, phenomena in the physical world, the technology, food and nutrition). They also concern central themes (free play, physical education, drama, music, arts and handicraft, social competences, language/language stimulation) from other parts of the Framework plan (Ministry of Education and Research, 2011).

Question 5 asked for the teachers' personal interests (Figure 5). The alternatives to choose for this closed-ended question are inspired by the questionnaire used in the ROSE (The Relevance of Science Education) project (Sjöberg \& Schreiner, 2006), a survey of interests for and attitudes towards science, technology and environmental challenges among 15-year-olds in many countries. The ROSE 
questionnaire also has influenced the alternatives of the questions 2-4. Additional, the early childhood teachers were asked if they like to work with science-related activities with the children, if they consider such activities as more demanding as others, and whether they would consider such activities as appropriate or even important for children, or not.

\section{The response}

Ninety-three early childhood teachers from 77 kindergartens returned a completed questionnaire. This is $65.5 \%$, which is a relatively good response rate (cf. Denscombe, 2007). From some few kindergartens there were several early childhood teachers who sent a response. Lack of time and an intense work situation were the most common reasons given for not responding to the questionnaire, followed by illness and the comment that the questionnaire was too extensive. Two responses (from two different kindergartens) were generally critical of the questionnaire. We may ask what kind of answers we would have received from those who did not send a response. Yet, we may suggest that most of those kindergartens with a certain priority for the science, environment and sustainability would perhaps also give priority to a questionnaire with a focus on these subjects. However, the response from the regular kindergartens was higher (67.6\%) than the response from nature kindergartens (42.3\%). It was more difficult to contact the staff at nature kindergartens; telephone calls gave the impression that they were rather busy outdoors with the children. Finally, 24 of the completed questionnaires came from nature kindergartens, 68 from regular kindergartens, while one additional kindergarten identified itself as both.

\section{The responders}

Among the 93 early childhood teachers who responded, all but 11 were women and their average age was 36.5 years. $76 \%$ of them were qualified early childhood teachers, while $5 \%$ were qualified in childcare and youth work. Other qualifications were child welfare officer (3\%), other social and health care workers (2\%), Physical education teacher (one man), and undefined education (3\%). Some of the early childhood teachers had advanced qualifications in preschool education (6\%), in other education (5\%) and in science and mathematics (one woman), while $3 \%$ were early childhood teacher students. One-third of the responses were from early childhood teachers only working with children o-3 years, while to-third were from those working with children aged 3-6 or 5-6 or with mixed age groups.

\section{RESULTS AND DISCUSSION}

\section{The findings}

The answers to five of the eight selected questions are presented in diagrams (Figures 1-5). About 90\% of the kindergartens studied, create a distinctive image for themselves by a superior focus area (Figure 1.). Figure 2 is showing the daily focusing of the kindergartens on science-related activities (nature and outdoor activities, sustainability, technology, biology and environment, physics, and chemistry), in comparison to some other central themes in early childhood education. The check marks for focusing on the different themes are categorized into a "strong/moderate", or "weak/no" focus (Figure 2). Figures 3 and 4 show the early childhood teachers' daily choices of activities, reflected by their ticks to various alternative themes, while respectively being indoors or outdoors with the children. The use of the various kinds of activities categorizes into "often, always", "sometimes" and "rarely". Figure 5 presents the early childhood teachers' own interests and preferences. All but one of the early childhood teachers agreed that it is important to encourage various science-related interests among young children. The great majority of them (all but five, three indifferent) answered that they like to work with activities related to natural sciences, and nearly all (except 6, three indifferent) answered that they were interested in the sciences. 


\section{Barbara Maria Sageidet}

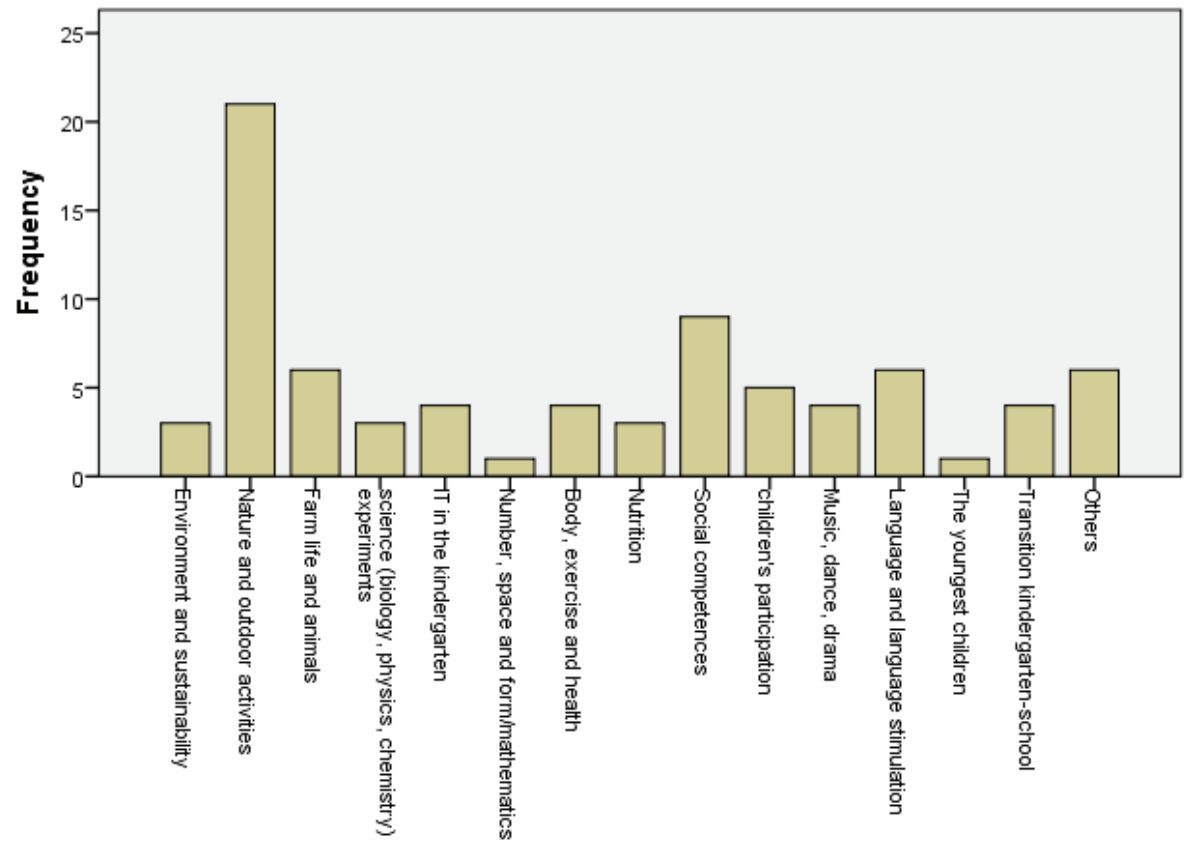

Figure 1. What is the superior focus area of the kindergarten? (frequency counts out of 93, $N=93$ ).

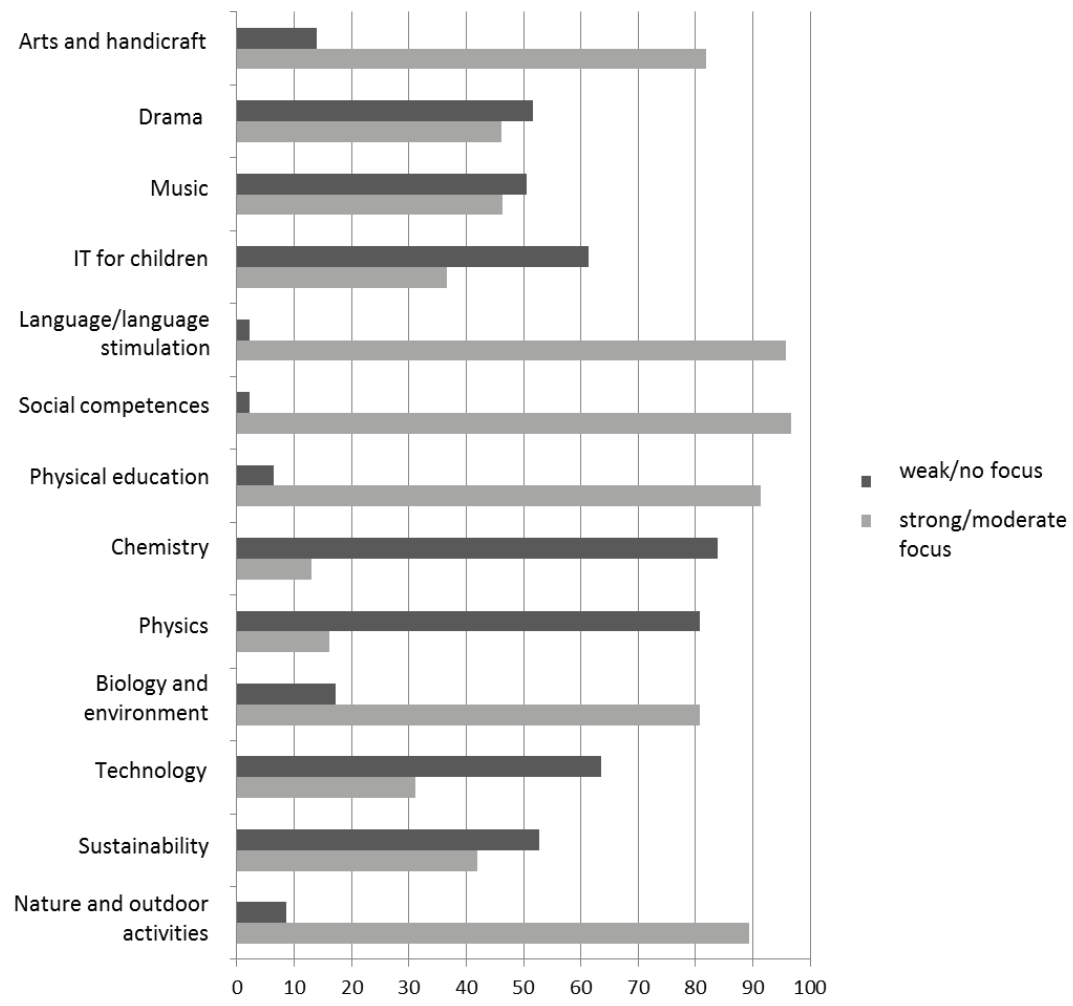

Figure 2. On an average day, our kindergarten has a focus on ... (frequency in \%, N=93). 


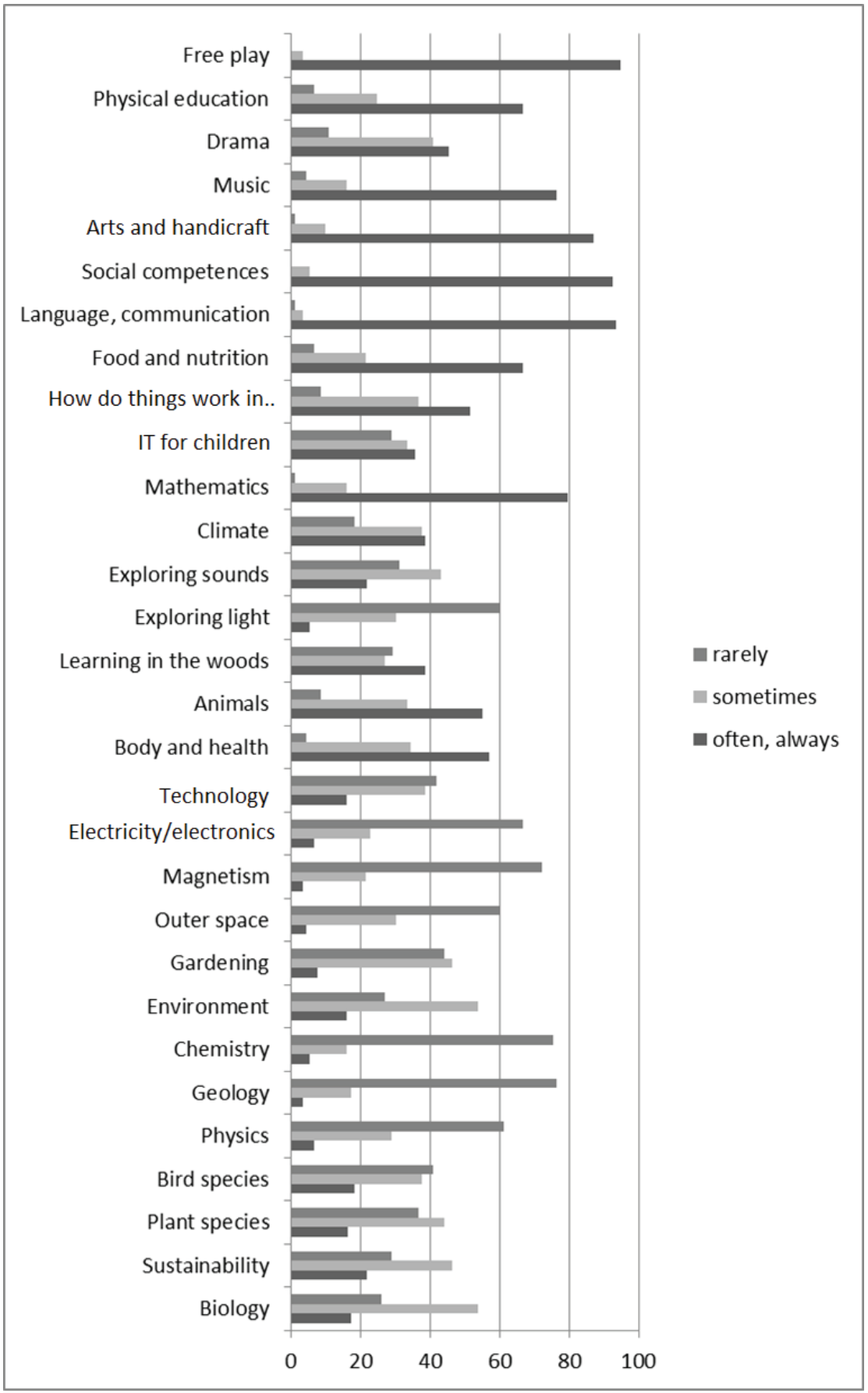

Figure 3. Daily activities indoors (frequency in \%, N=93). 


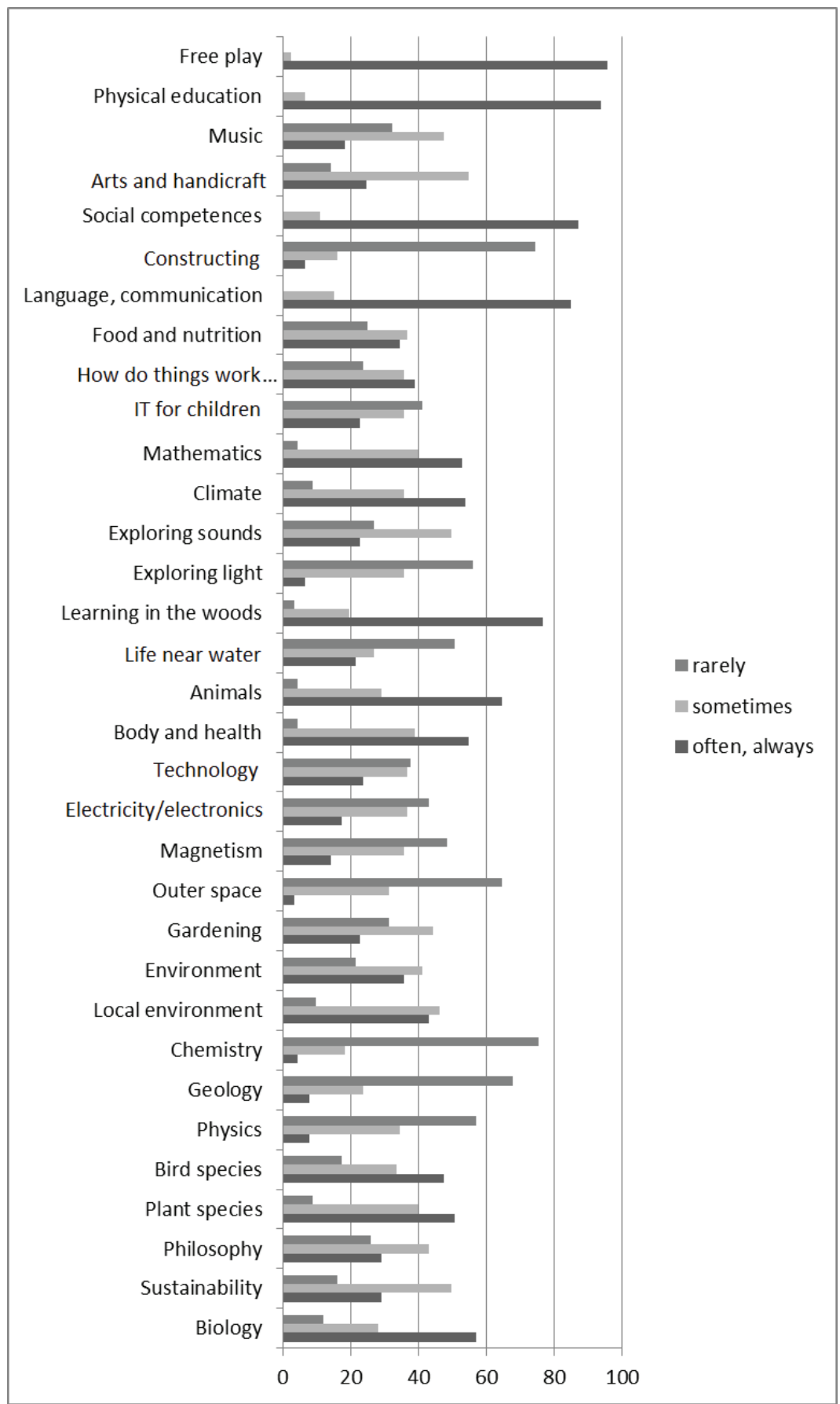

Figure 4. Daily activities outdoors (frequency in \%,N=93). 


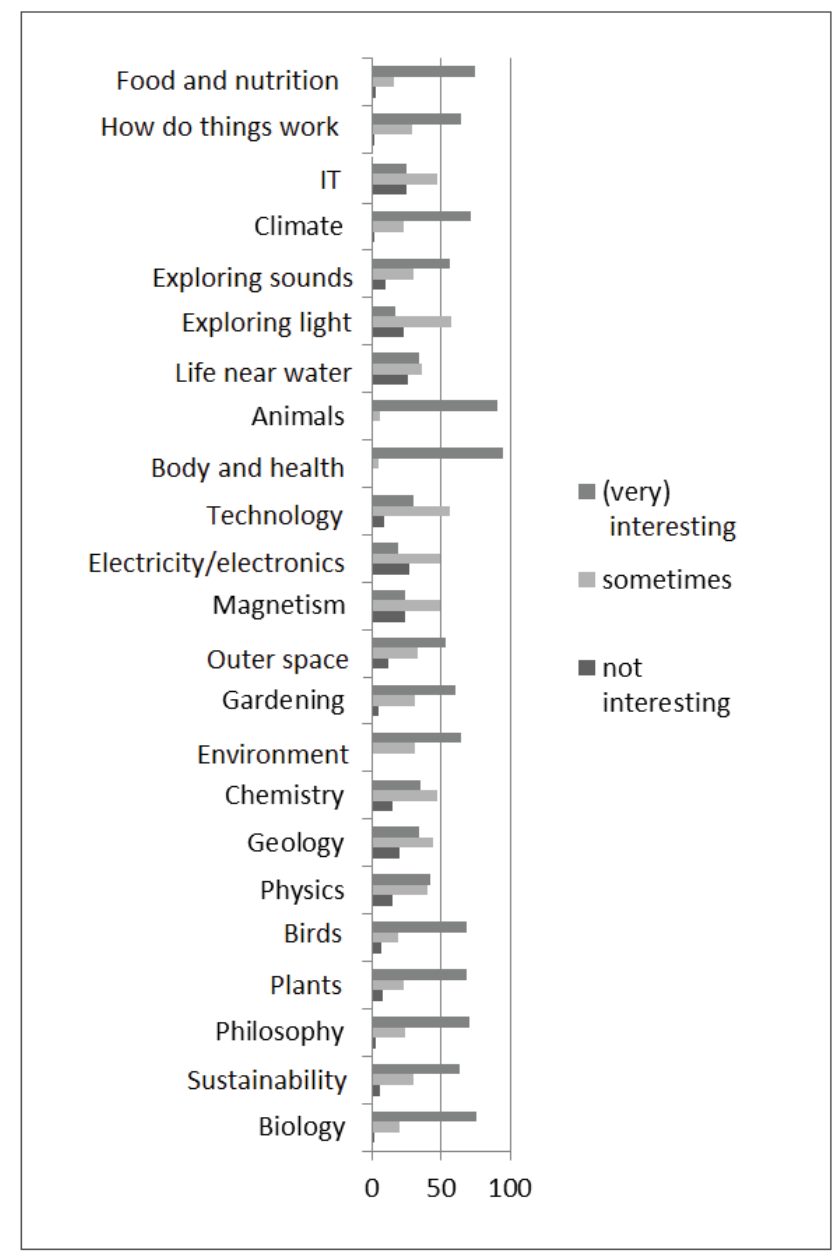

Figure 5. The early childhood teachers' own interests and preferences (frequency in \%, N=93).

The most frequently used subject areas for activities with children in the kindergarten's everyday life, with a special regard on science, technology, environmental issues and sustainability

Most of the kindergartens studied, had a superior focus area for their institution, and most often, this was 'nature and outdoor activities' (Figure 1). This focus was only slightly overrepresented in the nature kindergartens ( 6 of 16 in total). This finding underlines the Norwegian outdoor tradition (Aasen et al., 2009; Fjørtoft, 2001; Hammer \& Min He, 2014; Nilsen, 2008), and maybe a Norwegian self-image of being in close relationship with nature (Raabs, 2010). Discussions on nature as an area for experiences and learning have often focused on the importance of being in nature and of the direct contact by sensing of natural phenomena and elements. Yet, there is only little knowledge about how Norwegian kindergartens actually use the nature and outdoors, and about any subject-relations of the activities (Hallås \& Karlsen 2015). Three-quarters of the early childhood teachers asked in this study, have ticked for often choosing activities outdoors related to 'Learning in the woods'. About half of them have ticked for often choosing the subjects biology, plant species, and bird species (Figure 4). In preschool context, Sundberg and Ottander (2014) found science often equated with nature experiences (cf. Rambøll 2015). 
Free play is the activity marked as most frequently chosen by nearly all (about 95\%) of the early childhood teachers in this study, both indoors and outdoors (Figures 3 and 4). Physical education was in second place of popularity outdoors, and the checkmarks reflect that it was chosen often indoors, too (67\%). Social competences and language/communication scored also high.

According to the check marks, activities with mathematics were chosen often on an average day by more than half of the early childhood teachers of this study, both for indoors (79.5\%) and outdoors (53\%, Figures 4 and 5). Yet, only one of the kindergartens of this study had 'Number, space and form/ mathematics' as its superior focus area (Figure 1). Activities related to IT were, either often or sometimes chosen daily by about two-thirds of the early childhood teachers, both indoors and outdoors (Figures 4 and 5).

Sciences experiments (biology, physics, and chemistry), were hardly chosen as the kindergarten's superior focus area (Figure 1). Figure 2 shows that physics and chemistry had the lowest "strong/ moderate focus" frequencies for the kindergarten's focusing on an average day (16\%, and 13\%, respectively). As some informants came from the same kindergartens, the Figure 2 does not reveal the striking finding that only four of the 77 kindergartens studied had a strong daily focus on activities related to physics, and only two had any focus on activities related to chemistry. Only three kindergartens had a strong focus on activities related to technology, even if the rate is about $30 \%$ when summing up strong and moderate focuses (Figure 2). Technology was also chosen rather seldom for indoors ("often" 16\%) and outdoors activities ("often" 24\%), as reflected by the early childhood teachers check marks (Figure 3 and 4). Activities involving chemistry and geology were chosen most seldom, both indoors and outdoors, with an average score of $5 \%$ for "often". The same also applies to nearly all physics-related activities (physics, outer space, magnetism, electricity/electronics, exploring light), even if they show slightly higher average scores for outdoor activities (Figures 3 and 4). The reason for a rather high frequency of activities with exploring sounds (average score for 'often': 22\%), may be a relation to music activities. Music activities were chosen rather often according to the ticks (indoors by $76.5 \%$ and outdoors by $18.5 \%$ of the informants), and so were activities related to other traditional subjects like art and handicraft. They were "often" chosen indoors by $87 \%$ of the early childhood teachers, and outdoors by $25 \%$ of them (Figure 3 and 4 ).

\section{Relations between the early childhood teacher's priorities and their interests related to science}

Biology, environment, climate, plant and bird species were among the most popular personal interests of the early childhood teachers (Figure 5). Yet, according to the check marks, only a third of the early childhood teachers have often chosen the environment as a focus for outdoor activities (Figure 4). Climate, 'body and health', and 'food and nutrition' were chosen rather frequently for activities, possibly because these subjects are related to basic knowledge for small children, about the weather, their own bodies, and meals (Figures 3 and 4). 'Body and health' was, together with animals, on top of the early childhood teacher's own interests and preferences, ranked as "(very) interesting" by 94.5\% and $90.5 \%$, respectively. One-third of the early childhood teachers have rated chemistry as (very) interesting, but only a few actually did chemistry activities with the children. It is also striking that geology was marked as seldom chosen for daily activities in the kindergarten (Figures 3 and 4), although this subject was of fair interest among the early childhood teachers ("(very) interesting": $34.5 \%$, "sometimes": 44\%, Figure 5). This is difficult to understand, as geology is a subject, which can easily be included in outdoor activities. Similarly, many of the early childhood teachers checked for being sometimes or (very) interested in physics (82\%), outer space (87\%), exploring sounds (87\%), exploring light (74\%), and technology (86\%). But the use of these subjects in activities was rather rare.

On the other hand, activities related to IT were, according to the check marks, rather often chosen daily by about two-thirds of the early childhood teachers, even if only a quarter of the early childhood 
teachers were (very) interested in IT themselves (Figure 5). Subjects with somewhat higher frequencies for activities, but somewhat lower interest among the early childhood teachers were electricity/ electronics and magnetism. Although many of the early childhood teachers had an interest for it, there were only medium frequencies for activities with the children related to "how things work in everyday life' (indoors: “often” 51.5\%; outdoors: “often” 39\%, Figure 5).

It is interesting that the only early childhood teacher of this study with qualifications in science and mathematics do actually show her priority to activities related to science and mathematics.

\section{What can we learn from the study to strengthen the role of science, technology, environ- mental issues and sustainability?}

\section{Chemistry, geology, physics and technology were seldom in focus on an average day}

We may ask why chemistry, geology, physics and technology were seldom in focus on an average kindergarten day, and we may ask if this may be too seldom for to fulfill the requirements of the Framework Plan (Ministry of Education and Research, 2011). An exception in the present study was the only kindergarten with 'nature, environment and technology' as its superior focus area. It focused strongly on activities related to nature and the environment, physics, chemistry and technology.

The results of the present study show similarities with a study from the USA, which revealed that early childhood teachers were mostly (about $87 \%$ of the time) engaged in activities unrelated to science (Tu, 2006). Chemistry and physics were also the subjects with the lowest scores for Norwegian pupils in the TIMMS (Trends in international Mathematics and Science Study) tests in 2011 (Grønmo et al., 2012).

\section{The early childhood teachers had interest in science and liked to work with it}

Poor science teaching in preschool has previous been related to preschool teachers' negative attitude towards science, in combination with lack of competence and confidence (Garbett 2003; Spector-Levy, Kesner Baruch \& Mevarech, 2011; Sundberg \& Ottander, 2014). Negative attitudes towards science seem to occur in other groups of society, for example documented in the ROSE project (Sjøberg \& Schreiner, 2006). However, nearly all of the early childhood teachers in this study had some interest in science, and they seemed to be rather confident about science related activities with the children: Only 7 of the 93 early childhood teachers checked not liking to work with the sciences in their group of children (3 were indifferent). Most of them (75\%) stated that working with science activities is as easy as working with other kinds of activities in the kindergarten. Maybe these results are influenced by the increasing access to literature, guidelines and sources of inspiration and help (Christ, Espedal \& Daatland, 2011; Hammond, 2007; Jorde, 2013; Ormestad \& Øgrim, 1992; Wedøe, 2005; Øgrim \& Andersen, 2005), in addition to the government's promotion of science in 2010 (Ministry of Education and Research 2010). However, these results make it even more difficult to interpret why sciences-related activities are that underrepresented. Possibly the choice of activities relates to the need of special equipment and preparation (cf. Tu, 2006). Saçkes (2014) found that the availability of science-related instructional materials in the kindergartens is crucial.

\section{There were interests for sustainability and gardening but only few related activities}

The planned new Framework Plan (Eriksen Ødegaard et al., 2014) will set a strong focus on sustainability, defined in the Brundtland report (WCED, 1987), that has been internationally in focus for education (UNESCO 2005, 2012). Only three of the kindergartens of this study, two of which were nature kindergartens, had 'environment and sustainability' as their special focus area. Sustainability was not often chosen for activities, neither indoors (21,5\%, Figure 3) nor outdoors (by 29\%, Figure 4 ), although about $64 \%$ of the early childhood teachers were (very) interested in the environment and in sustainability. The preface of the ongoing governmental strategy underlines it's approach to 
sustainability and it's interdisciplinary perspectives (Ministry of Education and Research, 2015: 6). Sustainability is a genuine focus for interdisciplinary activities with small children that can involve nearly every subject of the curriculum (Sageidet, 2015; Davis \& Elliott, 2014; Siraj-Blatchford, Kimberly \& Pramling Samuelsen, 2010; UNESCO, 2005, 2012). An example of a science-related and interdisciplinary theme would be gardening (Sageidet, 2015; Siraj-Blatchford et al., 2010, p. 14; Watts, 2011). Gardening was not often chosen in this study, although a majority of the asked early childhood teachers (about 60\%) have an interest in it, and most kindergartens in Norway definitely have enough space for gardening.

\section{Competence seemed to be important for the choice of activities with the children}

The priorities of the only early childhood teacher of this study with qualifications in science and mathematics underline that competence seems to be an important factor for the choice of activities with the children. The early childhood teachers' interests (Figure 5) and their readiness to work with science is obviously a considerable potential to focus on. According to Østrem et al. (2009), early childhood teachers do want to update themselves in various subjects. Early childhood teachers should get the opportunity to develop their own interests and competences in terms of adaptation to use in the kindergarten, and such efforts should get acknowledgment. In this way, both the quantity and quality of the learning activities would be enhanced (cf. Kallery \& Psillos, 2001, Saçkes, 2014; Sageidet, 2012, 2015), and the early childhood teachers' function as "role models" would be strengthened.

Such an opportunity supplies the ongoing government's focus on science and mathematics education 2015-19 (Ministry of Education and Research, 2015). As there is limited knowledge about the actual needs of kindergartens and their stuff regarding useful science courses, the strategy's established 'science municipalities' and their kindergarten staff are encouraged to explain their needs and to ask for custom-made measures. However, such a self-evaluation may be a challenge for the participants, in a similar way as self-evaluation may have been a challenge for the informants of this study. It requires a good understanding about what science might look like in an everyday preschool context (Sundberg \& Ottander 2014; Tu 2006). Therefore, a continuous and open communication is necessary for the conceptualization of learning, in addition to a generosity from the involved universities and science centers.

According to six of the 23 personal comments added to the questionnaire of this study, the early childhood teachers recognized that reading the questions made them more conscious of their own influence on every day kindergarten practices related to science activities. In this way, the process of filling in the questionnaire of this study, as well as the participation in the government's promotion of science and mathematics, may give the individual early childhood teacher an opportunity for reflection on and inspiration for her or his work with the children.

According to this study, early childhood teachers seem to regard highly activities, which include natural or scientific phenomena, but they give less priority to more specific explorations of scientific concepts with the children (cf. Sundberg \& Ottander, 2014; Thulin, 2006). This means the loss of an important potential to enhance conceptual understanding in science by means of practical inquiry (Peterson \& French, 2008; Sageidet, 2012; Sundberg \& Ottander, 2014). Curricula and activities for young children should be developmentally appropriate, but they also need to reflect legitimate areas of knowledge that are of value to society (French, 2004; Hammer \& Min He, 2014; Lave \& Wenger, 1991; Rogoff, 2003; Saracho \& Spodek, 2008). These relations seem to be realized with regard to the rather frequent activities with mathematics and IT (Figures 3, 4).

\section{It seemed to be crucial to set a focus}

The superior focus areas of the kindergartens seem to be more important for the choice of activities than both the personal preferences of the individual early childhood teachers and the Framework 
Plan (Ministry of Education and Research, 2011). According to Østrem et al. (2009), the leaders of the kindergartens play an important role in the priorities given to the various subjects, in addition to internal culture or tradition, political signals, or requirements from the (local) authorities. The ongoing governmental strategy (Ministry of Education and Research 2015) considers these aspects. The strategy underlines that there is a need for more precise definitions and descriptions of the sciencerelated content of the subject area 'nature, environment and technology' in the Framework Plan (Ministry of Education and Research, 2011), and this need should influence the planned new Framework Plan (Eriksen Ødegaard et al. 2014), which is due in 2017.

\section{IMPLICATIONS AND SUGGESTIONS}

\section{Developing inquiry based and science-related interdisciplinary activities}

Nature and outdoor activities are prevailing activities in the kindergartens, while there is also an awareness of the importance of social competences and language stimulation. Why not combine 'social competences' and 'language and language stimulation', the second and third most important focus areas of the kindergartens studied (Figure 1 and 2), with scientific experiments in nature and outdoor settings? A stronger focus on interdisciplinary activities to combine the emphasis on both social competences and language training with practical scientific experiences in nature and outdoor settings can be realized in inquiry based approaches. Inquiry based learning is a method that has been increasingly recommended both internationally and for the use in the kindergarten (European Commission, 2004; Ministry of Education and Research, 2015; Rambøll, 2015; UNESCO 2012; Østergaard, 2012). Inquiry based learning involve children in explorative and collaborating activities with peers and adults, encouraging creativity, concentration on a common task, mutual consideration and critical thinking, understanding of interrelationships, and thirst for knowledge (Sageidet, 2012; Friedl \& Koontz 2005; Wells 1999; Østergaard, 2012; cf. Hope et al. 2013; cf. Kind, 2003; Lave \& Wenger, 1991; Rogoff, 2003; Vygotsky, 1986). Even though this kind of interdisciplinary work may be part of the everyday situation in many kindergartens, it has a huge, and hardly explored potential (Fjørtoft, 2001; Hallås \& Karlsen, 2015; Kükelhaus, 1995; Kvammen \& Synnes, 2012). Sensitivity-enhancing and enthusiastic communication with engaged adults also contributes to increase the vocabulary of even very young children (Hope et al., 2013). Only one of the 77 kindergartens has "The youngest children" as its superior focus area (Figure 1). The youngest children are an important part of the kindergartens' learning community (Jansen, 2013; cf. Fugelsnes, Röthle \& Johansson, 2013). Even though small children do not entirely understand the scientific idea behind experiments, they can gain benefit from peripheral participation as 'newcomers' (Lave \& Wenger, 1991). Such experiences are important for the promotion of interest, skills, and attitudes (Johnston, 2005; cf. Rogoff, 2003), and for their later understanding of scientific concepts, phenomena and ideas, as well as their mathematical development (Eshrad \& Fried, 2005; Havu-Nuutinen, 2005; Hope et al., 2013; Johnston, 2005, Saracho \& Spodek, 2008; Siry \& Max, 2013; cf. Kjærnsli \& Olsen, 2013).

Both sustainability in general and gardening in particular could provide varied inquiry based activities for practical learning about nature and culture, and their mutual relationships (Sageidet, 2015; Rogoff, 2003; Sundberg \& Ottander, 2014). Such activities can help children "to qualify for life" (Hallås \& Karlsen, 2015, p. 15; cf. Ministry of Eduation and Research 2012b, p. 2).

\section{More frequent activities related to chemistry, geology, physics and technology, with age adequate deepening}

The literature is clear about early mathematical experiences and their role for to overcome various challenges later in school (Fosse, 2012; Hope et al., 2013; Kjærnsli \& Olsen, 2013; Lerkkanen et al., 2012; Magnussen, Meyers, Ruhm \& Waldfogel, 2004; Ramey \& Ramey, 2004). The role of early experiences in sciences may appear more ambiguous (Rambøll, 2015). According to Lave and Wenger (1991) and Rogoff (2003), activities, learning events and repeated experiences in science-related 
themes will promote opportunities for learning both generally and within these themes. Sciencerelated activities may give the individual child motivation to learn more, a basis to ask questions, and not least a positive relationship to science. The more frequent we observe, investigate and talk about our observations, experiences and experiments, the more we need precise language and acquire an eye for detail. Frequent observations and experiments support the child's natural tendency to seek categories and patterns (Johnstone, 2005).

The current Norwegian Framework Plan for early childhood teacher education, implemented in 2012 (Ministry of Education and Research, 2012a), is based on groupings of the traditional subjects. This categorization may strengthen interdisciplinary work in kindergartens (BLU 2014, p. 84). Yet, it may also diminish the flexibility of inquiry based interdisciplinary work with a variety of combinations of subjects. It is important to maintain the possibility for appropriate focusing on and deepening in specific subjects, in particular chemistry, physics, geology and technology (Ministry of Education and Research, 2013; 2014).

\section{CONCLUSION}

This study may contribute to a still uncomplete overview of early childhood teacher's everyday priorities given to activities with the children related to science, technology, environmental issues and sustainability. In spite of plenty of personal interest in science-related subjects, the early childhood teachers of this study report that activities related to chemistry, geology, physics, technology, gardening and sustainability are rather seldom in their kindergartens. Nature and outdoor activities are most popular, followed by activities related to social competences, language stimulation and physical education.

Both learning theories and research, as well as the government's focus on science and mathematics education (2015-19), underline the importance of frequent opportunities for science-related activities in the kindergarten.

This study shows that early childhood teachers have useful and partly science-related interests that provide an extensive and broadly untapped potential for activities in the kindergarten. However, science activities often need both special competences and considerable preparation and equipment; this might suggest that the additional work by the early childhood teachers should be more readily facilitated and better appreciated. Appropriate science competence among early childhood teachers is necessary to increase children's opportunities to gain specific science-related experiences.

Teacher training and courses for further education should give high regard to the understanding of the science-related contents of the subject area "nature, environment and technology" in the Framework Plan, in addition to the use of interdisciplinary and inquiry based activities in the kindergarten. The early childhood teacher's personal interests represent a useful potential for building up and developing science-related competences.

Science-related activities are rather seldom in the kindergartens of this study. It is important to prevent a further decrease of activities related to science, technology, environmental issues and sustainability, and to allow children to gain regular experience of these important subjects.

\section{ACKNOWLEDGEMENT}

Many thanks to Eva Johansson, Marit Alvestad, Aud Torill Meland, Reidar Mosvold, and especially to Donna Berthelsen for critical comments on versions of this manuscript and for inspiring communications. Thanks to Paul Farmer for improving the language. The study was granted by the Faculty of Arts and Education, University of Stavanger, Norway. 


\section{REFERENCES}

Aasen, W. Grindheim, L.T. \& Waters, J. (2009). The outdoor environment as a site for children's participation, meaning-making and democratic learning: examples from Norwegian kindergartens. Special Issue: International Perspectives on Outdoor and Experiential Learning. Education 3-13: International Journal of Primary, Elementary and Early Years Education, 37(1), 5-13.

Alvestad, M. (2004). Årsplanar i barnehagen - intensjonar og realitetar i praksis? Norsk pedagogisk tidsskrift, 2004(1), 89-101.

Alvestad, T. \& Løvberg, R. (2005). Barnehagen i endring, hva tenker førskolelærere om det? Norsk Pedagogisk tidsskrift, 2005(5), 344-353.

Berge, A. (2012). Barnehagens læringskulturer - underveis mot vekslende læringshorisonter. In T. Vist \& M. Alvestad M. (Eds.), Læringskulturer i barnehagen - Flerfaglige forskningsperspektiver. (pp. 44-66). Cappelen Damm Akademisk.

BLU (2014). Frå Førskolelærar til barnehagelærar. Den nye barnehagelærarutdanninga - Muligheiter og utfordringar. Rapport nr.1 fra følgegruppen for barnehagelærerutdanning (BLU) til Kunnskapsdepartementet, http://www.hib.no/siteassets/bilder-sentre/suf/pdf/rapport-frafoelgegruppe-blu-2014.pdf

Bowman, B.T. (1999). Policy implications for math, science, and technology in early childhood education. In American Association for the Advancement of science, Dialogue on early childhood science, mathematics, and technology education (pp. 40-49). Washington DC: AAAS.

Christ, I., Espedal, L. I. \& Daatland, D.D. (2011). Teamwork, training and technology for development of key competence. Pedagogiske opplegg prøvd ut i prosjektet: KeyTTT Comenius Multilateral Project. Stavanger: Omega Trykk, 34 p.

Davis, J.M. \& Elliott, S. (Eds.) (2014), Research in Early Childhood Education for Sustainability. International perspectives and provocations. Routledge, $337 \mathrm{p}$.

Denscombe, M. (2007). Good research guide. Open University Press, 359.

Eriksen Ødegaard, E., Aukland, S., Gjems, L., Pålerud, T., Seland, M. \& Grande Røys, H. (2014). Tekstforslag til revidert rammeplan for barnehagen. Utdanningsdirektoratet. Retrieved January 7, 2016 from http://www.udir.no/contentassets/d9b3d406b2694e878f630c778cd5621a/ tredjeutkast-rammeplan-19-02-2014.pdf

Eshach, H \& Fried, M. (2005). Should science be taught in early childhood? Journal of Science Education and Technology, 14(3), 315-336.

European Commission (2004). Europe needs more scientists! Report by the High Level Group on Increasing Human Resources for Sciences and Technology in Europe. Brussels: European Commission. Retrieved January 7, 2016 from http://ec.europa.eu/research/conferences/2004/sciprof/ pdf/conference_review_en.pdf

Fayez, M., Sabah, S. A. \& Oliemat, E. (2011). Jordanian early childhood teachers' perspectives toward science teaching and learning. International Research in Early Childhood Education, 2(1), 7695.

Fjørtoft, I. (2001). The Natural Environment as a Playground for Children: The Impact of Outdoor Play Activities in Pre-Primary School Children. Early Childhood Education Journal, 29(2), 111117.

Fosse, T. (2012). (Ed.), Rom for matematikk i barnehagen. Caspar forlag, $137 \mathrm{p}$.

French, L. (2004). Science as the center of a coherent, integrated early childhood curriculum. Early Childhood Research Quarterly, 19, 138-149.

Friedl, A.E \& Koontz, T.Y. (2005). Teaching Science to children - An inquiry approach. New York: The McGraw-Hill Companies, Inc., 459 p.

Fugelsnes. K., Röthle, M.A. \& Johansson, E.M. (2013). Values at stake in interplay between toddlers and teachers. Part 8. In O. F. Lillemyr, S. Dockett \& B. Perry (Eds.), Varied Perspectives on Play and Learning: Theory and Research on Early Years Education (pp. 109-125), Information Age Publishing. 
Garbett, D. (2003). Science education in early childhood teacher education: Putting forward a case to enhance student teachers' conficence and competence. Research in Science education, 33(4), 467-81.

Grønmo, L.S., Onstad, T., Nilsen, T., Hole, A., Aslaksen, A. \& Borge I.C. (2012). Framgang, men langt fram. Norske elevers prestasjoner i matematikk og naturfag i TIMMS 2011. Oslo: Akademika forlag, $138 \mathrm{p}$.

Hallås, B. O. \& Karlsen, G., Eds. (2015). Natur og danning. Profesjonsutøvelse, barnehage og skole. Fagbokforlaget, 293 p.

Hammer, A. S. E. \& Min He (2014). Preschool teachers approaches to science: a comparison of a Chinese and a Norwegian kindergarten. European Early Childhood Education Research Journal, published online 30.okt.2014. Retrieved January 7, 2016 from http://dx.doi.org/10.1080/1350 293X.2014.970850

Hammond, R. (2007). Action! Fysikk og eksperimenter. Oslo: Cappelen, 96 p.

Havu-Nuutinen, S. (2005). Examining young children's conceptual change process in floating and sinking from a social constructivist perspective. International Journal of Science Education, 27(3), 259-279.

Hope, K. G., Schachter, R.E. \& Wasik, B. A. (2013). Using the Scientific Method to Guide Learning: An Integrated Approach to Early Childhood Curriculum. Early Childhood Education Journal, $41,315-323$.

Interest. (n.d. 2011) American Heritage $\AA$ Dictionary of the English Language, Fifth Edition. Retrieved November 12, 2015 from http://www.thefreedictionary.com/interest

Jansen, K.E. (2013). På sporet av medvirkning og læring: de yngste barna og spenningsfeltet mellom det planlagte og det spontane. Bergen: Fagbokforlaget, $168 \mathrm{p}$.

Johannessen, A. (2009). Introduksjon til SPSS. Fjerde utgave. Oslo: Abstrakt forlag. $187 \mathrm{s.}$

Johansson, E. \& Samuelssen, I. P. (2009). To weave together - play and learning in early childhood education. Journal of Australian Research in Early Childhood Education,16(1), 33-48.

Johnston, J. (2005). Early explorations in science. Exploring primary science and technology. Buckingham: Open University Press.

Jonassen, D.H. \& Rohrer-Murphy, L. (1999). Activity Theory as a Framework for Designing Constructivist Learning Environments. Educational Technology Research and Development 47(1), 61-79.

Jorde, D. (2013). Forskerfrø.no. Naturfagsenteret. Retrieved January 7, 2016 from http://www. naturfag.no/nyhet/vis.html?tid=1997935

Kallery, M. (2004). Early-years teachers' late concerns and perceived needs in science: an exploratory study. European Journal of Teacher Education 27(2), 147-165.

Kallery, M. \& Psillos, D. (2001). Preschool teachers' content knowledge in science: their understanding of elementary science concepts and of issues raised by children's questions. International Journal of Early Years Education 9(3), 165-179.

Kilgore, S. B. \& Pendleton W.W. (1993). The organizational context of learning: framework for understanding the acquisition of knowledge. Sociology of Education 66(1), 63-87.

Kind, P.M. (2003). Praktisk arbeid og naturvitenskapelig allmenndannelse. In D. Jorde \& B. Bungum (Eds.), Naturfagdidaktikk, perspektiver, forsking og utvikling. Oslo: Gyldendal Akademisk Forlag, 226-244.

Kjærnsli, M. \& Olsen, R. V. (2013) (Eds.), Fortsatt en vei å gå: norske elevers kompetanse i matematikk, naturfag og lesing i PISA 2012. Universitetsforlaget, $304 \mathrm{p}$.

Kükelhaus, H. (1995). Fassen Fühlen Bilden - 6. Auflage - Köln: Gaia Verlag.

Kvammen, P. I. \& Synnes, K. (2012). Den lever $i$ hånda mi - Magiske smådyr på land. Naturfag.no -Nyhetsbrev Thursday, 2 February 2012. Retrieved May 31, 2014 from http://www.naturfag.no/ artikkel/vis.html?tid=1869395

Lave, J., \& Wenger, E. (1991). Situated learning: Legitimate peripheral participation. Cambridge, England: Cambridge University Press, 138 p. 
Lerkkanen, M.-K., Kiuru, N., Pakarinen, E., Viljaranta, J., Poikkeus, A.-M., Rasku-Puttonen, H., Siekkinen, M. \& Nurmi, J.-E. (2012). The role of teaching practices in the development of children's interest in reading and mathematics in kindergarten. Contemporary Educational Psychology 37(4), 266-279.

Magnussen, K., Meyers, M., Ruhm, C. \& Waldfogel, J. (2004). Inequality in preschool education and school readiness. American Education Research Journal 41, 115-157.

Ministry of Education and Research (2006). Stortingsmelding nr. 16 (2006-2007) ...og ingen sto igjen. Tidlig innsats for livslang learing. Oslo: Kunnskapsdepartementet.

Ministry of Education and Research (2009). Kvalitet $i$ barnehagen. St.meld.nr.41 (2008-2009). Oslo: Kunnskapsdepartementet.

Ministry of Education and Research (2010). Realfag for framtida - Strategi for styrking av realfag og teknologi 2010-2014. Retrieved June 3, 2014 from www.regjeringen.no/en/archive/Stoltenbergs-2nd-Government/Ministry-of-Education-and-Research/Nyheter-og-pressemeldinger/nyheter/2010/realfag-for-framtida-.html?id=614237

Ministry of Education and Research (2011). Rammeplan for barnehagens innhold og oppgaver (Framework Plan for the Content and Tasks of Kindergartens). Revised edition, 61p. Retrieved January 7, 2016 from http://www.udir.no/globalassets/upload/barnehage/rammeplan/rammeplan_bokmal_2011nett.pdf

Ministry of Education and Research (2012a). Nasjonal forskrift om rammeplan for barnehagelærerutdanning. Fastsatt av Kunnskapsdepartementet 04.06.2012 med hjemmel i lov om universiteter og høyskoler av 1. april $2005 \mathrm{nr} .15 \S 3$ 3-2 annet ledd. Retrieved June 3, 2014, from http://www. regjeringen.no/nb/dep/kd/dok/lover_regler/forskrifter/2012/nasjonal-forskrift-om-rammeplan-for-barn.html?id=684087

Ministry of Education and Research (2012b).Kunnskap for en felles fremtid. Revidert strategi for utdanning for bærekraftig utvikling (2012-2015). Utdanningsdirektoratet 2012. Retrieved Januar 7, 2016 from http://www.regjeringen.no/upload/KD/Vedlegg/UH/Rapporter_og_planer/ Strategi_for_UBU.pdf

Ministry of Education and Research (2013). Status, juni 2013, for strategien Realfag for fremtida 201O-2014. Retrieved Januar 7, 2016 from http://www.nito.no/dm/public/374379.PDF

Ministry of Education and Research (2014) Realfag - relevante, engasjerende, attraktive, lærerike. Rapport fra ekspertgruppa for realfagene (Bergem, O. K., Goodchild, S., Henriksen, E. K., Dankert Kolstø, S. Nortvedt, G.A. \& Reikerås, E.), Retrieved Januar 7, 2016 from https://www. regjeringen.no/globalassets/upload/kd/vedlegg/rapporter/rapport_fra_ekspertgruppa_for_ realfagene.pdf

Ministry of Education and Research (2015). Tett på realfag. Nasjonal strategi for realfag i barnehagen og grunnopplæringen (2015-2019). Retrieved Januar 7, 2016 from https://www.regjeringen.no/ no/dokumenter/tett-pa-realfag/id2435042/

Nilsen, R.D. (2008). Children in nature: cultural ideas and social practices in Norway, Chapter European childhoods, pp. 38-6o. Basingstoke: Palgrave Macmillan.

Ormestad, H. \& Øgrim, O. (1992). Fysikk på roterommet: leker og forsøk i skole og barnehage. Oslo: Universitetsforlaget, $107 \mathrm{p}$.

Peterson, S. M. \& French, L. (2008). Supporting young children's explanations through inquiry science in preschool. Early Childhood Research Quarterly 23, 395-408.

Raabs, N. K. (2010). No child in the Norwegian Woods? - A study on education for sustainable development in Norwegian Primary Schooling. Masteroppgave, Senter for utvikling og miljø, Universitetet i Oslo, $109 \mathrm{p}$.

Rambøll (2015). Kunnskapsgrunnlaget - realfag i barnehagen. Oslo: Rambøll management, 41 p. Retrieved January, 7, 2016 from http://www.udir.no/Upload/Forskning/2015/realfag\%20i\%20 barnehagen.pdf?epslanguage $=$ no

Ramey, C. T. and Ramey, S. L. (2004). Early learning and school readiness: Can early intervention make a difference? Merrill-Palmer Quarterly 50, 471-491. 
Rogoff, B. (2003). The cultural nature of human development. New York: Oxford University Press.

Sageidet, B.M. (2012). Inquirybaserte naturfagaktiviteter i barnehagen. In T. Vist \& M. Alvested

(Eds.), Læringskulturer i barnehagen - faglige forskningsperspektiver (pp. 115-139). Cappelen Damm Akademisk.

Sageidet, B.M. (2015). Bærekraftig utvikling i barnehagen - bakgrunn og perspektiver. Norsk pedagogisk tidsskrift 99 (2), 110-123.

Säljö, R. (2001). Læring i praksis - et sosiokulturelt perspektiv. Oslo: Cappelens forlag a.s., 276 p.

Saçkes M. (2014). How often do early childhood teachers teach science concepts? Determinants of the frequency of science teaching in kindergartens. European Early Childhood Education Research Journal 22(2), 169-184.

Saracho, O.N. \& Spodek, B. (2008) (Eds.), Contemporary perspectives on science and technology in early childhood education. Contemporary perspectives in early childhood education. Information Age Publishing Inc., 186 p.

Siraj-Blatchford, J., Kimberly, C. Smith \& Pramling Samuelsen, I. (2010). Education for Sustainabile Development in the Early Years. OMEP (World Organization for Early Childhood Education), Retrieved January 7, 2016 from http://www.327matters.org/Docs/ESD\%20Book\%20Master. pdf

Siry, C. \& Max, C. (2013). The collective construction of a science unit: Framing curricula as emergent from kindergarteners'wonderings. Science Education 97(6), 878-902.

Sjøberg, S. (2009). Naturfag som allmenndannelse - en kritisk fagdidaktikk. 3rd Edition. Gyldendal Academisk.

Sjøberg, S. \& Schreiner, C. (2006). Holdninger til og forestillinger om vitenskap og teknologi i Norge - En fremstilling basert på data fra Eurobarometer og ROSE, Norges Forskningsråd NFR, nettpublikasjon, 136 p. Retrieved November 27, 2013 from www.forskningsradet.no/no/Nyhet/Ja+ til+vitenskap+men+ikke+som+karriere/1153831952342

Spector-Levy, O., Kesner Baruch, Y. \& Mevarech, Z. (2011). Science and scientific curiosity in preschool - The teacher's point of view. International Journal of Science Education, iFirst Article, 1-28.

Sträng, M.H. \& Åberg-Bengtsson, L. (2009). 'From the Mountain and then?’ Five-year-olds visiting the 'way of water' exhibition at a science centre. International Journal of Early Childhood, 41,1.

Sundberg, B. \& Ottander C. (2014). Sciece in preschool - a foundation for education for sustainability. A view from Swedish preschool teacher education. In J. M. Davis \& S. Elliott (Eds.), Research in Early Childhood Education for Sustainability. International perspectives and provocations. Routledge, pp. 280-293.

Sylva, K., Siraj-Blatchford, I., Taggart, B., Sammons, P., Melhuish, E. Ellio, K. \& Totsika, V. (2006). Capturing quality in early childhood through environmental rating scales. Early Childhood Research Quarterly 21, 76-92.

Sylva, K., Taggart, B., Siraj-Blatchford, V.T., Ereky-Stevens, K. Gilden, R. \& Bell, D. (2007). Curricular quality and day-to-day learning activities in pre-school. International Journal of Early Years Education 15(1), 49-65.

Thoresen, I.T. (2009). Barnehagen i et utdanningspolitisk kraftfelt. Nordisk barnehageforskning 2, 3.

Thulin, S. (2006). Vad händer med lärandets objekt? En studie av hur lärare och barn i förskolan kommunicerar naturvitenskapeliga fenomen. Acta Wexionensia 102/2006, Växjö University Press, $134 \mathrm{p}$.

$\mathrm{Tu}, \mathrm{T}$. (2006). Preschool science environment: What is available in a preschool classroom? Early Childhood Educational Journal 33, 245-251.

UNESCO (2005). UN Decade of Education for Sustainable Development. Paris: UNESCO. Retrieved January 7, 2016 from http://unesdoc.unesco.org/images/o014/o01416/141629e.pdf

UNESCO (2012). Shaping the education of tomorrow, Paris:UNESCO, $89 \mathrm{p}$. 
Van Peer, W., Hakemulder, F. \& Zyngier, S. (2012). Scientific methods for the humanities. John Benjamin Publishings Company, 328 p.

Vejleskov. H. (1999). Udvalgte Piaget tekster: Uddrag fra Piagets værker med innledende kommentarer.Copenhagen: Dansk Psylologisk Forlag, 267 p.

Vygotzky, L.S. (1986). Thought and Language. Cambridge, MA: Harvard University Press.

Watts, A. (2011). Every nursery needs a garden. A step-by-step guide to creating and using a garden with youn children. Routledge, 131 p.WCED (1987). Our Common Future. A report from the United Nations World Comission on Environment and Development. Oxford University Press.

Wedøe, L. (2005). Fysikkaktiviteter i barnehage og småskole. 1. utgave 1995, Oslo: J.W. Cappelens Forlag, $305 \mathrm{p}$.

Wells, C. G. (1999). Dialogic Inquiry - Towards a sociocultural practice and theory of Education. Cambridge University Press, 354 p.

Wertsch, J.V. \& Sohmer, R. (1995). Vygotsky on learning and development. Human Development 38, 332-37.

Zacharos, K., Antonopoulus, K. \& Ravanis, K. (2013). Activities in mathematics education and teaching interactions. The costruction of the measurement of capacity in pre-schoolers. European Early Childhood Education Research Journal 19(4), 451-468.

Zetterqvist, A. \& Kärrqvist, C. (2007). Naturvitenskap med yngre barn: En forskningsoversikt. Gothenborg: University of Gothenborg.

Ärlemalm-Hagsér, E. \& Sandberg, A. (2011). Sustainable development in early childhood education: in-service students' comprehension of the concept. Environmental Education Research, 17(2), 187-200.

Øgrim, O. \& Andersen, S. Lilledal (2005). Eksperimentboka: 191 forsøk fra Fysikk på roterommet. Oslo: Kolofon, 150 p.

Østergaard, L.D. (2012). Inquiry based science education og den sociokulturelt forankrede dialog $\mathrm{i}$ naturfagsundervisningen. NorDiNa 8(2), 162-170.

Østrem, S. (2007). Barnehagen som læringsarena - Realisering av tanken om anerkjennelse, Nordic studies in education $2007(3)$.

Østrem, S., Bjar, H., Rønning Føsker, L., Dehnæs Hogsnes, H., Thorsby Jansen, T., Nordtømme, S. \& Rydjord Tholin, K. (2009). Alle teller meir. Rapport 1/2009 Høgskolen i Vestfold. Tønsberg: Høgskolen i Vestfold, 248 p. 